\title{
Comparing the Protection Imparted by Different Fraction Extracts of Garlic (Allium sativum L.) against Der p-Induced Allergic Airway Inflammation in Mice
}

\author{
Chia-Chen Hsieh ${ }^{1,+}{ }^{,}$Keng-Fan Liu ${ }^{2,+}$, Pei-Chun Liu ${ }^{3}$, Yaw-Tsan Ho ${ }^{4}$, Wei-Sung Li ${ }^{2,5}{ }^{\oplus}$, \\ Wen-Huang Peng ${ }^{2, *}$ and Jen-Chieh Tsai ${ }^{3, *(1)}$ \\ 1 Department of Medicine Division of Chest Medicine, Cheng Ching Hospital, No. 966, Sec. 4, Taiwan Road, \\ Taichung 40764, Taiwan; pokyhsieh@gmail.com \\ 2 School of Chinese Pharmaceutical Sciences and Chinese Medicine Resources, China Medical University, \\ No. 91, Hsueh-Shih Road, Taichung 40402, Taiwan; cell77821@yahoo.com.tw (K.-F.L.); \\ weisungli@tari.gov.tw (W.-S.L.) \\ 3 Department of Medicinal Botanicals and Health Applications, Da-Yeh University, No. 168, University Road, \\ Chunghua 30012, Taiwan; ivy86825@gmail.com \\ 4 Department of Emergency Medicine, Taipei Tzu Chi Hospital, Buddhist Tzu Chi Medical Foundation, \\ No. 289, Jianguo Road., Xindian District, New Taipei City 23142, Taiwan; yth471105@tzuchi.com.tw \\ 5 Plant Pathology Division, Taiwan Agricultural Research Institute, Council of Agriculture, Executive Yuan, \\ Wufeng 41362, Taiwan \\ * Correspondence: whpeng@mail.cmu.edu.tw (W.-H.P.); jenchieh@mail.dyu.edu.tw (J.-C.T.); \\ Tel.: +886-422-053-366 (W.-H.P.); +886-4851-1888 (J.-C.T.) \\ + These authors contributed equally to this work.
}

Received: 17 August 2019; Accepted: 29 September 2019; Published: 1 October 2019

check for updates

\begin{abstract}
Garlic (Allium sativum L.) has been used extensively as a food ingredient and medicinally, but the effect on asthmatic airway inflammation has not been studied in detail. We accordingly explored the protective effects exerted by various garlic fraction extracts against airway inflammation with Dermatophagoides pteronyssinus (Der p)-induced allergic asthma in vivo and in vitro. Garlic extraction was realized using $\mathrm{n}$-hexane, dichloromethane, ethylacetate, $\mathrm{n}$-butanol, and water in sequence to obtain different fraction extracts. Mice were orally administered different fractions $(80 \mathrm{mg} / \mathrm{kg})$ daily for four weeks. The histological results showed that the water fraction could ameliorate lung-based goblet cell hyperplasia, inflammatory cell infiltration, and mucus hypersecretion. The water fraction extracts decreased IgE and IgG1, and they decreased inflammatory cells as quantified in bronchoalveolar lavage fluid (BALF); however, they increased IgG2a in serum. Moreover, the water fraction extracts increased IFN- $\gamma$ and IL-12 (both constituting Th1 cytokines) in BALF, but they reduced IL-13, -4 , and -5 (all constituting Th 2 cytokines), and also inhibited the expression of IL-1 $\beta$, IL- 6 , and TNF- $\alpha$. The water fraction also inhibited the PI3K/Akt/NF-kB signal pathways in A549 cells. These findings suggest that water fraction extracts of garlic have a clear anti-inflammatory effect on Der p-induced allergic asthma.
\end{abstract}

Keywords: garlic; asthma; Der p; anti-inflammatory; Th1/Th2

\section{Introduction}

Characterized by sensitive trachea and bronchial inflammation, asthma currently constitutes a frequently occurring chronic inflammatory respiratory disease [1]. Asthma usually involves different reversible airflow obstruction, resulting in repeated wheezing, shortness of breath, and rapid coughing that occurs most often in the morning and at night [2,3]. Environmental and climate changes have 
engendered a rise in the incidence of asthma worldwide. Incidence rates for allergic asthma are particularly high in children, leading to the condition taking on particular importance [4].

Asthma symptoms are triggered by a variety of immune, genetic, and environment-related interactions [5,6]. The activation of Type $2 \mathrm{~T}$ helper (Th2) cells is associated with inflammatory reactions, and this causes tracheal hypersensitivity owing to cytokine release, including interleukin (IL)-13, -5 , and $-4[7,8]$. Additionally, B cells are spurred by Th2 cells to activate mast cells, which release more inflammatory and allergic mediators, leading to Immunoglobulin E (IgE) production [9]. Corticosteroids are the most commonly used drugs against asthma clinically [10]. However, these drugs are unable to prevent asthma symptoms in some patients. Furthermore, these drugs can produce unacceptable side effects, which limit their application. Therefore, new drugs must be developed that directly alleviate the symptoms of asthma without excessive side effects.

Previous studies indicated that administration of Dermatophagoides pteronyssinus (Der $\mathrm{p}$ ) significantly increased pro-inflammatory cytokines such as interleukin-6 (IL-6), interleukin-1 $\beta$ (IL-1 $\beta$ ), and tumor necrosis factor- $\alpha$ (TNF- $\alpha$ ) in mice lung tissues [11]. IL-6 play a crucial role in the production of Th2 cytokines and inflammatory cell recruitment in the asthmatic airways of mice [12]. Increased inflammatory cytokines in the airway epithelium, such as IL-1 $\beta$, IL-4, and TNF- $\alpha$, were also observed in asthma [13]. Phosphoinositide 3-kinases (PI3K)/Akt and nuclear factor-kB (NF-kB) pathway participate in the regulation of inflammatory mediators [14]. NF- $\mathrm{kB}$ is a key transcription factor in the pathogenesis of asthma, and phosphorylation of NF- $\mathrm{kB}$ regulates the physiology of many cells, including inflammation, immune response, apoptosis, and cell death $[15,16]$.

Garlic (Allium sativum L.) of the family Liliaceae is a perennial herb with a well-known and pungent odor. Garlic has been widely used as a food ingredient and spice since ancient times. Garlic also has favorable physiological activity, and it has been used to treat various conditions such as cardiovascular disease [17] and hyperlipidemia [18]. The major active components of garlic are sulfur compounds containing alliin, allicin, diallylsuifide, diallyl disulfide, diallyltrisulfide, and S-allylcysteine (SAC) [19]. A previous study found that water extracts of garlic can increase T cell cytotoxicity and lymphoproliferative capacity [20]. In Taiwan, garlic is used as a traditional folk medicine to prevent cold, cough, asthma, and bronchitis. Some people also place garlic in boiling water to obtain garlic water and drink it to prevent asthma attacks. In our previous studies, we have confirmed the protective effect of purified garlic extract on dust Der p-induced allergic airway inflammation in mice [21]; however, the mechanisms and the active components are unclear. To investigate, we used different polar solvents to obtain stratified extracts of garlic and estimated their effects on and relevant mechanisms behind mouse allergic airway inflammation engendered by Der $\mathrm{p}$.

\section{Results}

\subsection{Effects Exerted on Total Inflammatory Cell Count in Bronchoalveolar Lavage Fluid (BALF)}

Relative to the control group, the total inflammatory cell count determined in the asthmatic mice was significantly increased, as seen in Figure $1(p<0.001)$. However, the mentioned count was significantly reduced by treatment with water fraction extracts (WA) and n-butanol fraction extracts (BU) at $80 \mathrm{mg} / \mathrm{kg}(p<0.05)$. Moreover, as revealed by the results, no significant difference was revealed in the treatment with n-hexane fraction extracts (HE), dichloromethane fraction extracts (DI), and ethyl acetate fraction extracts (EA). 


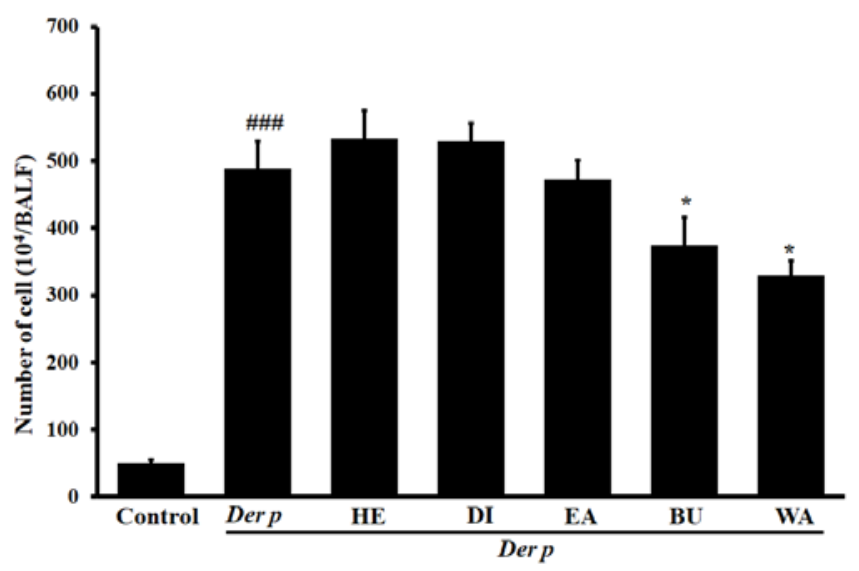

Figure 1. Effects of different fractions of garlic extracts $(80 \mathrm{mg} / \mathrm{kg})$ on the total inflammatory cell count in the collected bronchoalveolar lavage fluid (BALF) of mice with Der p-induced allergic asthma. Data derived are presented herein as mean \pm SEM. ${ }^{\# \#} p<0.001$ versus the control group, ${ }^{*} p<0.05$ versus the Der p group.

\subsection{Pathological Results on Der p-Induced Lung and Trachea Injuries}

Histopathology results revealed that, when exposed to Der $p$, the lung tissues of the acquired mice expressed moderate inflammatory cell infiltration, mainly eosinophils and lymphocytes, around perivascular and per bronchial space when compared with the control group, as seen in Figure 2A,B. The morphology of the eosinophils and lymphocytes in Figure 2C are as follows: Eosinophils have a bi-lobed nucleus, with highly condensed chromatin, express numerous granules stain various shades of orange, pink, or red with eosin in the cytoplasm. Lymphocytes have a relatively large, dense, often eccentric nucleus that is round and may be slightly indented. The histological changes are evaluated following previous study [22], and the results are presented in Table 1. In comparison with the Der p control group, WA fraction exhibited decreased inflammatory cell infiltration in the lungs, as seen in Figure 2G; however, inflammatory cell infiltration in the HE, DI, EA, BU fractions was not significantly reduced, as seen in Figure 2C-F, respectively. These results indicated that, in asthmatic mice, the WA fraction can inhibit Der p-induced inflammatory infiltration.

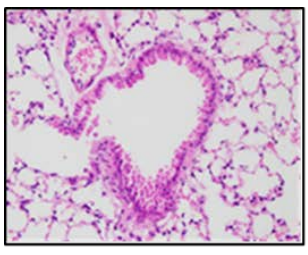

(A) Control

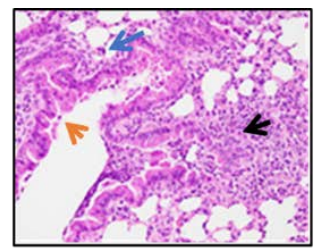

(B) $\operatorname{Der} p$

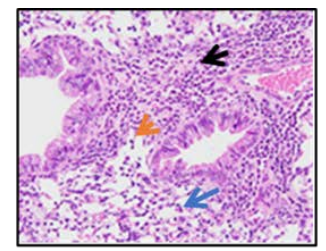

(C) $\mathrm{HE}$

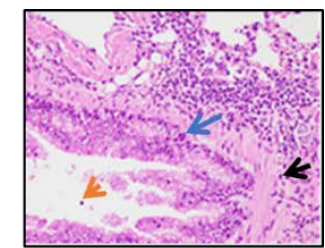

(D) $\mathrm{DI}$

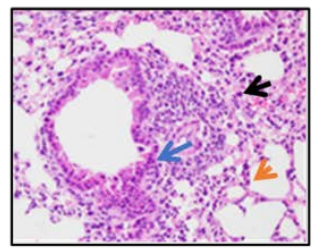

(E) EA

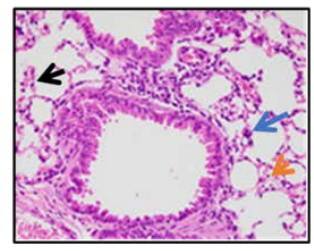

(F) BU

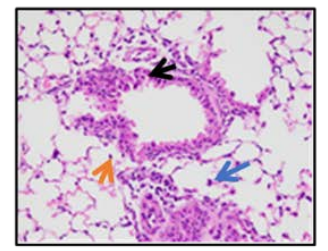

(G) WA

Figure 2. Histopathological findings in the lungs of mice with Der p-induced allergic asthma. Eosinophil is indicated by black arrows, macrophage is indicated by blue arrows and lymphocyte is indicated by orange arrows. (A) control group; (B) Der p group; (C) n-hexane fraction group; (D) dichloromethane fraction group; (E) ethyl acetate fraction group; (F) n-butanol fraction group; (G) water fraction group. (H\&E staining, original magnification $400 \times$ ). 
Table 1. Quantitative summary of the protective effects of different fraction extracts of garlic on Der p-induced allergic asthma based on histological observations.

\begin{tabular}{|c|c|c|c|c|c|c|c|c|}
\hline \multirow{3}{*}{ Organ } & \multirow{3}{*}{ Histopathological Findings } & \multicolumn{7}{|c|}{ Groups $^{1}$} \\
\hline & & \multirow{2}{*}{ Control } & \multirow{2}{*}{$\operatorname{Der} p$} & \multicolumn{5}{|c|}{$\operatorname{Der} p$} \\
\hline & & & & HE & DI & EA & BU & WH \\
\hline \multirow[t]{3}{*}{ Lung } & Aggregation, macrophage and giant cells, alveolar, focal & $0.0 \pm 0.00$ & $2.5 \pm 0.22 \#$ & $2.0 \pm 0.00$ & $1.8 \pm 0.38$ & $1.8 \pm 0.19$ & $1.5 \pm 0.22$ & $0.8 \pm 0.19 *$ \\
\hline & Epithelial hyperplasia, bronchial, focal & $0.0 \pm 0.00$ & $2.0 \pm 0.00^{\#}$ & $2.0 \pm 0.00$ & $1.5 \pm 0.38$ & $1.5 \pm 0.22$ & $1.0 \pm 0.31$ * & $1.0 \pm 0.31$ * \\
\hline & Mucification, goblet, bronchial, focal & $0.0 \pm 0.00$ & $2.0 \pm 0.00^{\#}$ & $1.8 \pm 0.19$ & $1.5 \pm 0.38$ & $1.5 \pm 0.22$ & $1.0 \pm 0.31 *$ & $1.0 \pm 0.31 *$ \\
\hline Brachus & Inflammation, submucosal, focal & $1.0 \pm 0.00$ & $3.3 \pm 0.58^{\#}$ & $2.3 \pm 0.58$ & $2.0 \pm 0.82$ & $2.0 \pm 0.82$ & $1.5 \pm 0.58$ & $1.3 \pm 0.43^{*}$ \\
\hline
\end{tabular}

${ }^{1}$ Degree of lesions was graded from one to five depending on severity: $1=$ minimal $(<1 \%) ; 2=\operatorname{slight}(1-25 \%) ; 3=$ moderate $(26-50 \%) ; 4=$ moderate/severe (51-75\%); $5=$ severe/high

(76-100\%). " Statistically significant difference between control and Der $\mathrm{p}$ groups at $p<0.05{ }^{*}$ Statistically significant difference between Der $p$ and treated groups at $p<0.05$. 
Moreover, bronchial epithelial hyperplasia and goblet cell modification in the bronchus were observed alongside macrophage aggregation in the terminal bronchioles, as seen in Figure 3A,B. The histological changes are evaluated following previous study and the results are also presented in Table 1. In comparison with the Der p control group, the WA fraction group exhibited decreased infiltration in the bronchus, as seen in Figure 3G; however, monocyte infiltration was not significantly reduced in the HE, DI, EA, and BU fractions, as seen in Figure 3C-F. Thus, in asthmatic mice, the WA fraction seemingly inhibits Der $\mathrm{p}$-induced inflammatory infiltration.

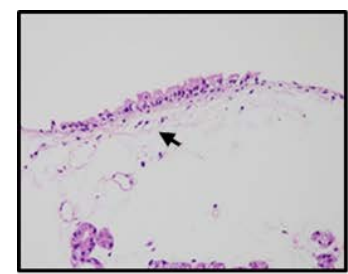

(A) Control

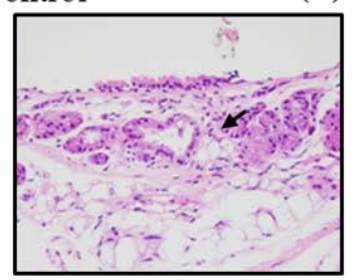

(E) EA

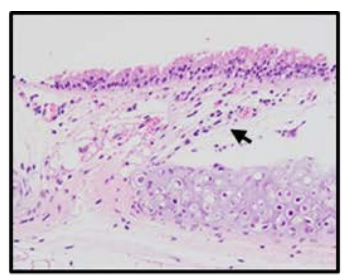

(B) $\operatorname{Der} p$

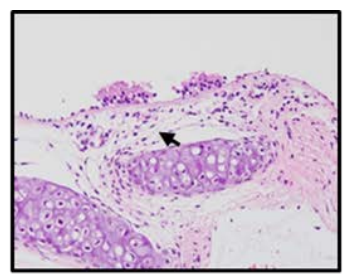

(C) $\mathrm{HE}$

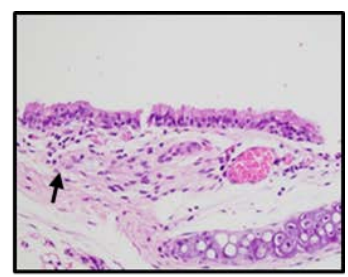

(D) DI

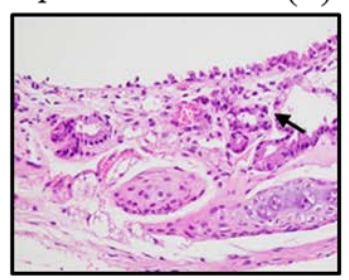

(F) BU

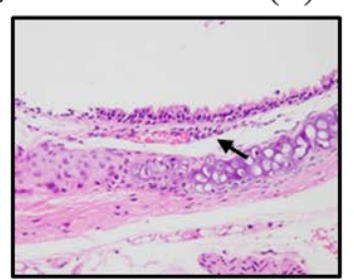

(G) WA

Figure 3. Histopathological findings in the bronchus of mice with Der p-induced allergic asthma. Inflammatory cell infiltration is indicated by black arrows. (A) control group; (B) Der p group; (C) n-hexane fraction group; (D) dichloromethane fraction group; (E) ethyl acetate fraction group; (F) n-butanol fraction group; (G) water fraction group. (H\&E staining, original magnification 400×).

\subsection{Effects on Der p-specific serum levels of Immunoglobulin G2a (IgG2a), Immunoglobulin G1 ( IgG1) and IgE}

Significant elevations were noted in the serum levels of IgE and IgG1 in the mice with Der p-induced allergic asthma relative to the included controls $(p<0.05)$, as outlined in Figure 4A,B. However, $80 \mathrm{mg} / \mathrm{kg}$ of the WA and BU was determined to significantly attenuate the observed serum levels of $\operatorname{IgE}(p<0.05)$, and $80 \mathrm{mg} / \mathrm{kg}$ of the WA was noted to significantly attenuate the observed serum levels of IgG1. Conversely, the WA $(80 \mathrm{mg} / \mathrm{kg})$ also increased IgG2a serum levels, as seen in Figure $4 \mathrm{C}$ $(p<0.01)$. No significant differences were noted following treatment with the HE, DI, and EA.

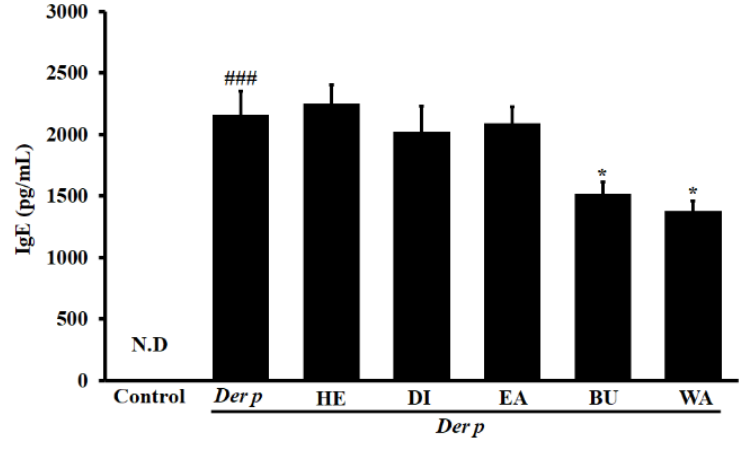

(A)

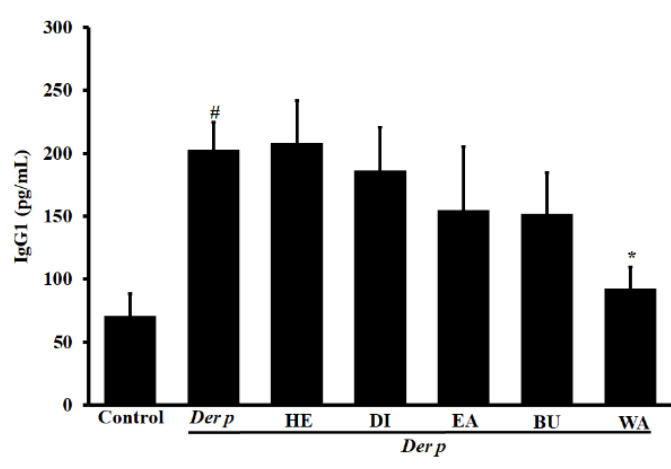

(B)

Figure 4. Cont. 


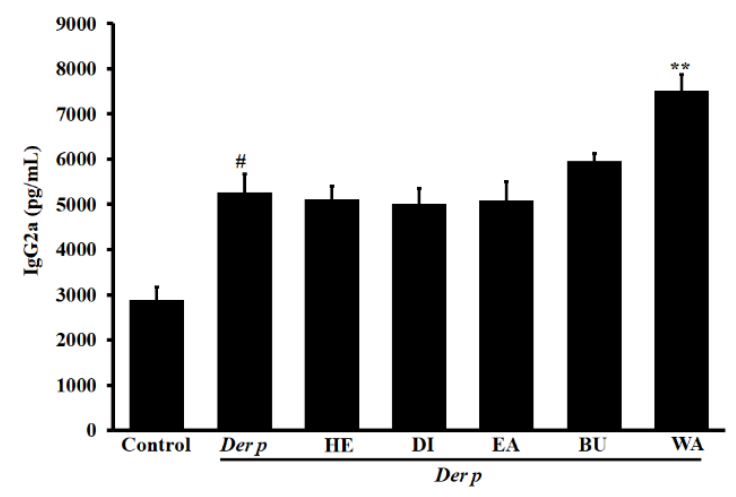

(C)

Figure 4. Effects of different fractions of garlic extracts $(80 \mathrm{mg} / \mathrm{kg})$ on serum (A) IgE, (B) IgG1 and (C) IgG2a in mice with Der $\mathrm{p}$-induced allergic asthma. Data are expressed as mean \pm SEM. ${ }^{\#} p<0.05$ and \#\#\# $p<0.001$ versus the control group, ${ }^{*} p<0.05$ and ${ }^{* *} p<0.01$ versus the Der $p$ group.

\subsection{Effects on Cytokine Levels in the BALF of Mice with Der p-Induced Allergic Asthma}

A Th1 and Th2 cytokine imbalance is characteristic of bronchial and tracheal inflammation in asthma. Therefore, to determine the extent to which different fractions of garlic extracts modulate this imbalance, this study quantified the Th1 and Th2 cytokine levels. As displayed in Figure 5, in the Der p group's BALF, the Th2 cytokine levels of Interleukin (IL)-13, -4 , and -5 were noted to increase significantly, but the Th1 cytokine levels of Interleukin-12 (Il-12) and INF- $\gamma$ were noted to decrease significantly. After treatment executed using different fractions of garlic extracts, the WA fraction decreased the levels of the observed Th2 cytokines IL-13, -4 , and -5 but increased the levels of the Th1 cytokines IL-12 and INF- $\gamma$ when compared with the Der p group. However, the HE, DI, EA, and BU fractions exhibited neither reductions in the observed levels of the Th2 cytokines nor increases in the observed levels of the Th1 cytokine.

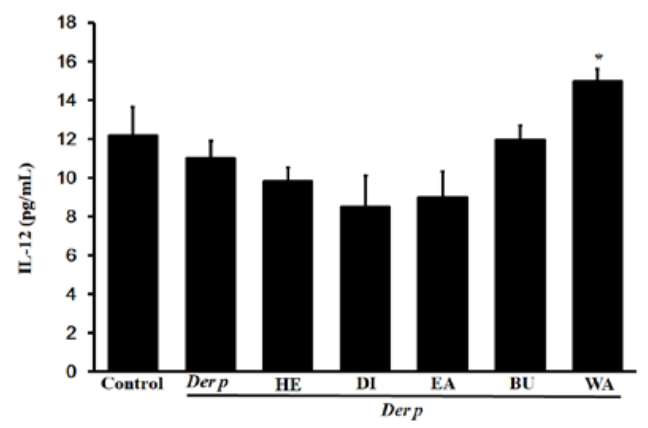

(A)

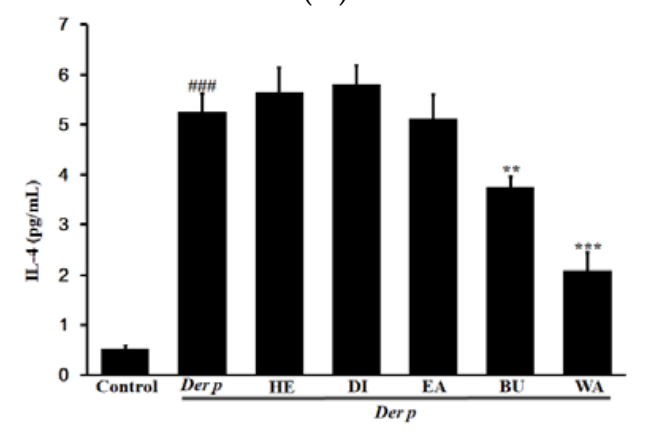

(C)

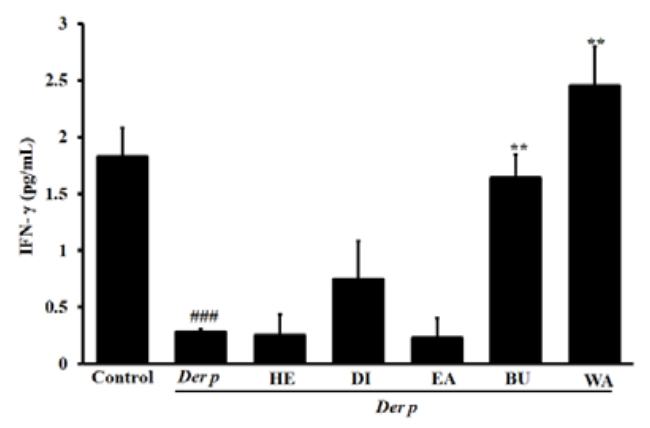

(B)

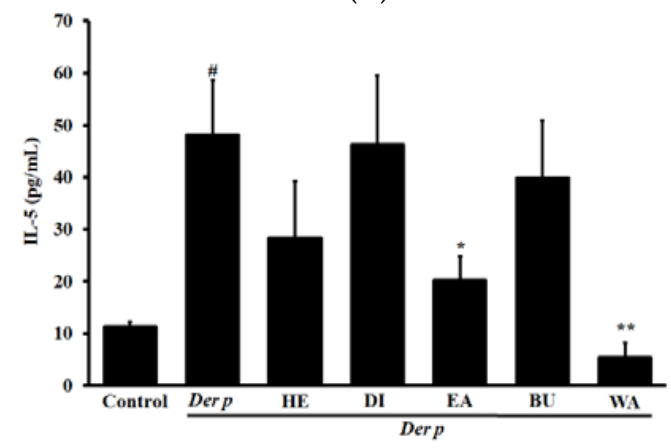

(D)

Figure 5. Cont. 


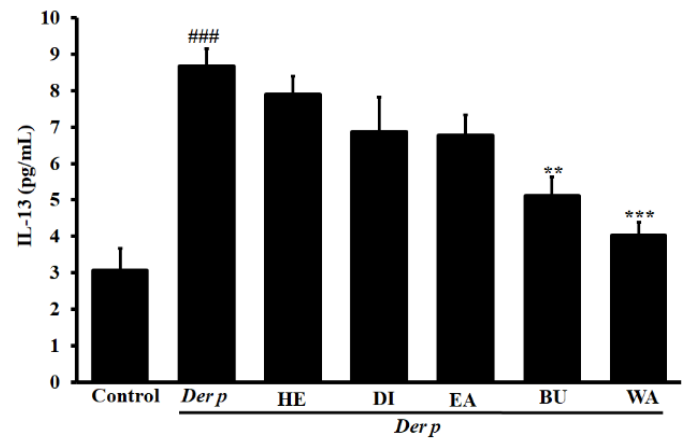

(E)

Figure 5. Effects of different fractions of garlic extracts $(80 \mathrm{mg} / \mathrm{kg})$ on (A) IL-12, (B) INF- $\gamma$, (C) IL-4, (D) IL-5 and (E) IL-13 cytokine levels in the collected BALF of mice with Der p-induced allergic asthma. Data derived are presented herein as mean \pm SEM. ${ }^{\# \#} p<0.001$ versus the control group, ${ }^{*} p<0.05$, ** $p<0.01$ and ${ }^{* * *} p<0.001$ versus the Der $p$ group.

\subsection{Effects on Pro-Inflammatory Cytokine Levels in Der p-Induced Lung Tissues of Mice}

Figure 6 displayed the results of activations of IL- $1 \beta$, IL- 6 , and TNF- $\alpha$ in the lungs of various fraction extract groups and Der $p$ group. The levels of IL- $1 \beta$, IL- 6 , and TNF- $\alpha$ in the Der $p$ group were higher than control group. However, treatment the with WA significantly reduced the levels of IL-1 $\beta$, IL-6, and TNF- $\alpha$. However, there were no significant changes by treatment with the HE, DI, EA, or BU fractions.

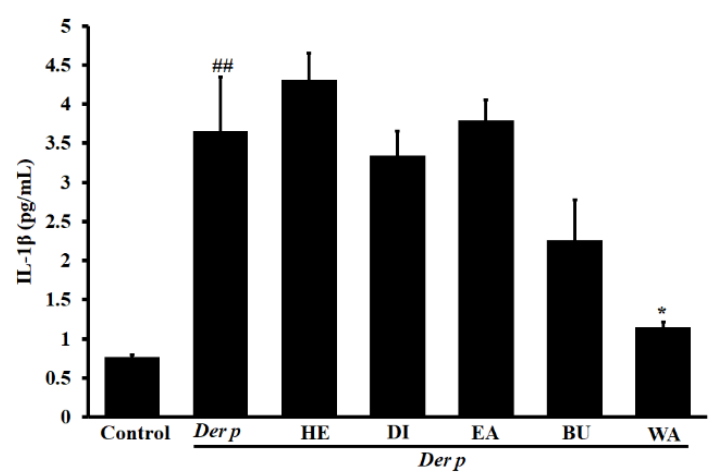

(A)

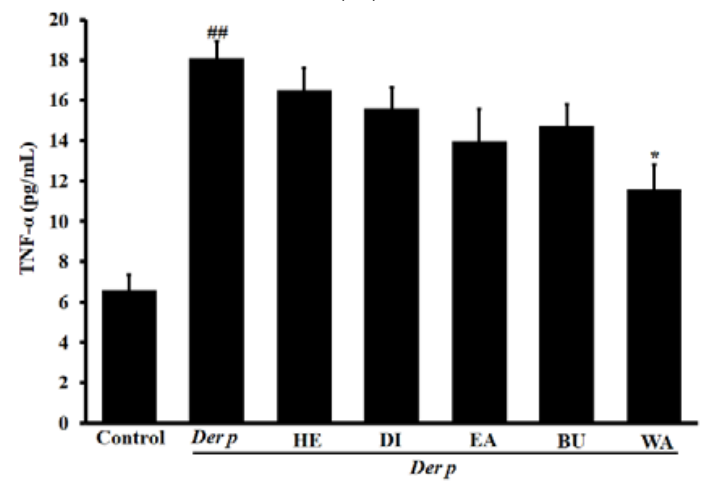

(C)

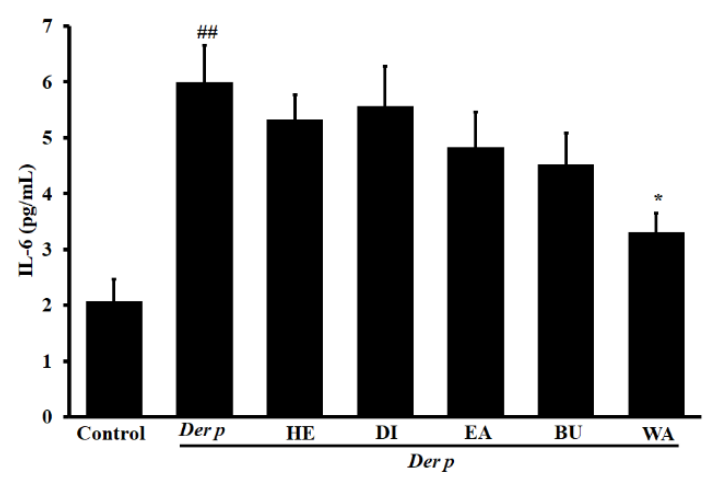

(B)

Figure 6. Effects of different fractions of garlic extracts $(80 \mathrm{mg} / \mathrm{kg}$ ) on (A) IL-1 $\beta$, (B) IL-6 and (C) TNF- $\alpha$ pro-inflammatory cytokine levels in the collected lung tissue of mice with Der $\mathrm{p}$-induced allergic asthma. Data derived are presented herein as mean \pm SEM. ${ }^{\#} p<0.01$ versus the control group, * $p<0.05$ versus the Der $p$ group. 


\subsection{Effect of Water Fraction Extracts (WA) on IL-6/PI3K/Akt/NF- $k B$ Pathway in Der p-Stimulated A549 Cells}

In the present study, we evaluated whether WA fraction inhibited the IL-6/PI3K/Akt/NF- $\mathrm{KB}$ pathway in in Der p-stimulated A549 cells by Western blotting methods. As shown in Figure 7, it was observed that WA fraction significantly suppressed the gene expression of IL-6, PI3K, and IKB kinase (IKK). Additionally, WA fraction also inhibited and phosphorylations of Akt and NF-kB compared with Der $\mathrm{p}$ group. Thus, these results indicated that WA fraction inhibited the IL-6/PI3K/Akt/NF-kB pathway in Der p-stimulated A549 cells.

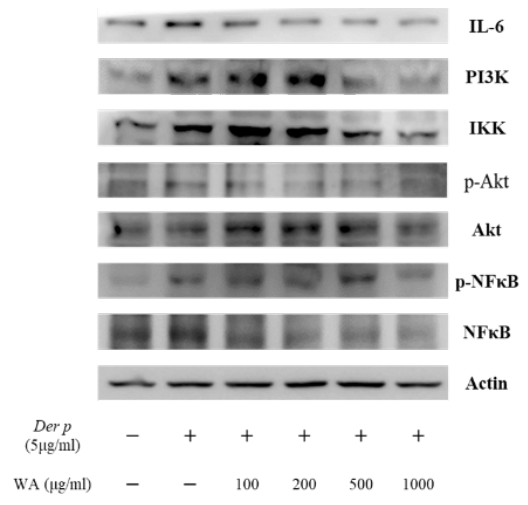

(A)

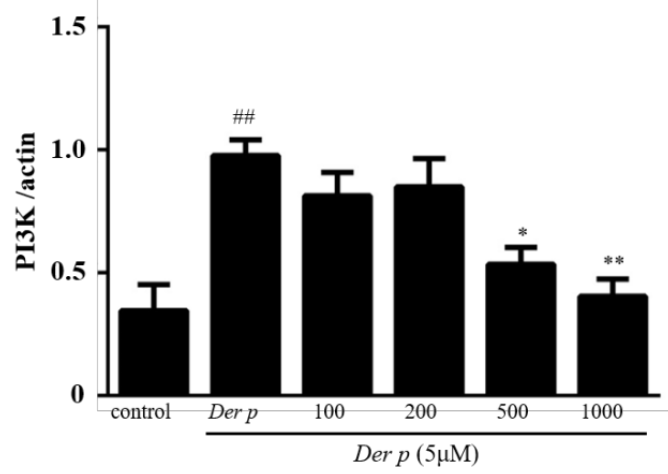

(C)

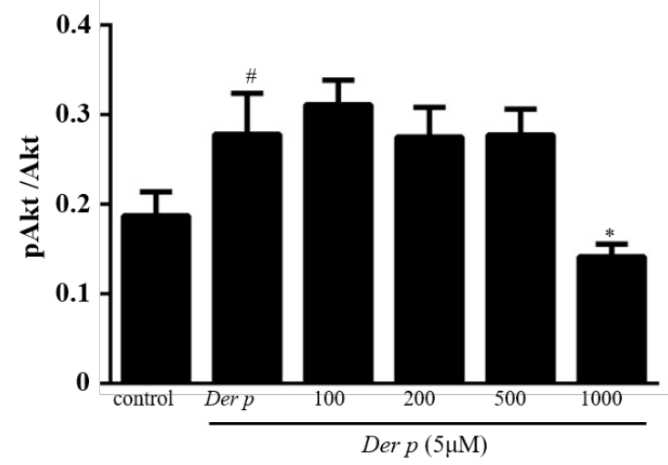

(E)

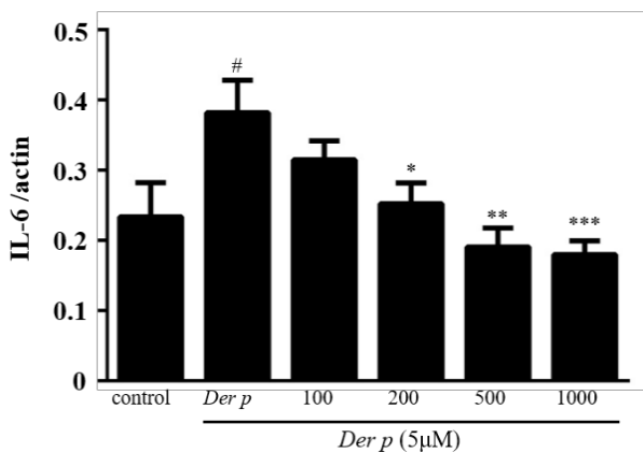

(B)

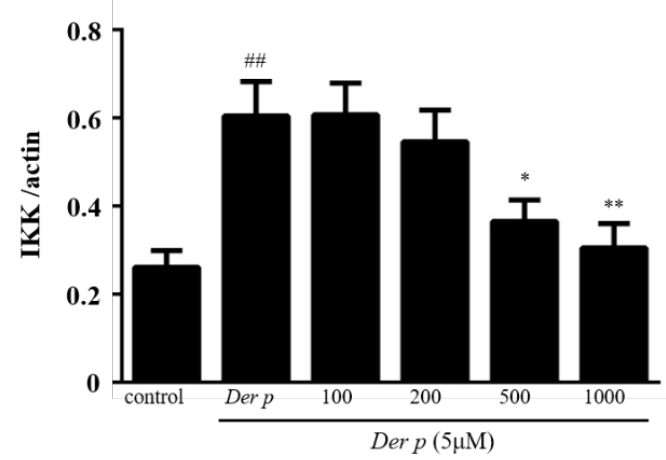

(D)

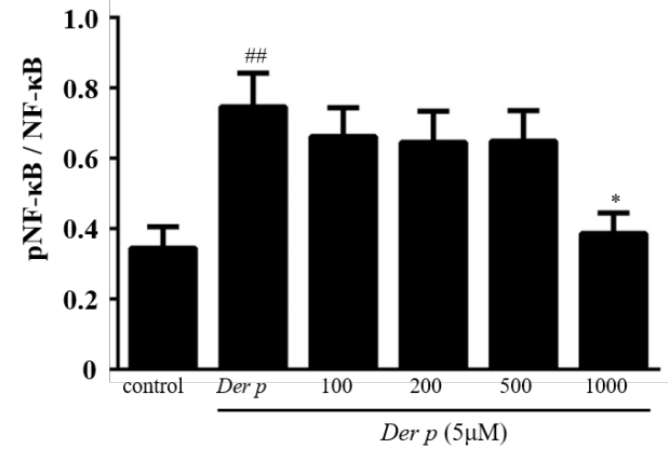

(F)

Figure 7. Effect of WA fraction on IL-6/PI3K/Akt/NF-kB expression in Der p-stimulated A549 cells. The cells were pretreated without (-) treatment (Control), with (+) Der-p alone or Der-p plus various concentrations $(100,200,500$, and $1000 \mu \mathrm{M})$ of WA fraction for $24 \mathrm{~h}(\mathrm{~A})$. Proteins isolated from A549 cells were probed with antibodies against (B) IL-6, (C) PI3K, (D) IKK, (E) p-Akt, and (F) p-NFkB. The same membrane was re-probed with the antibody for $\beta$-actin to verify that equal amounts of protein were loaded. Data derived are presented herein as mean \pm SEM. ${ }^{\#} p<0.05$ and ${ }^{\# \#} p<0.01$ versus the control group, ${ }^{*} p<0.05,{ }^{* *} p<0.01$ and ${ }^{* * *} p<0.001$ versus the Der $p$ group. 


\subsection{High-Performance Liquid Chromatography (HPLC) Analysis of the WA Fraction}

As shown in Figure 8, the peak of SAC was detected at a retention time of $5.97 \mathrm{~min}$ in the standard chromatogram. A similar peak was revealed in the WA chromatogram, suggesting the presence of $\mathrm{SAC}$ in the water fraction extract of garlic.

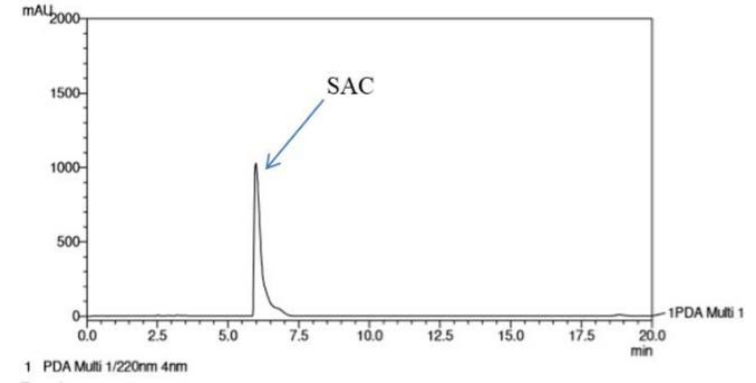

(A)

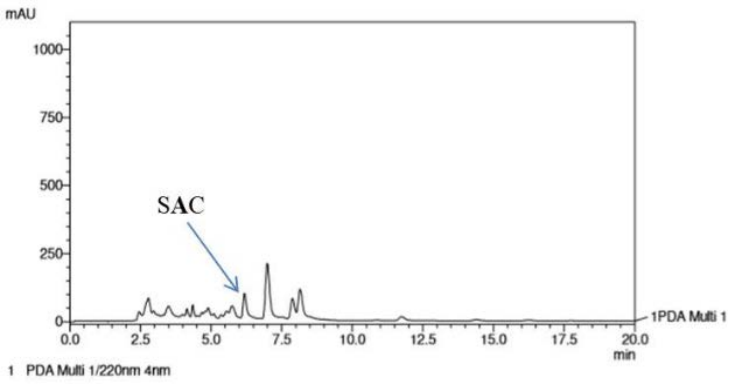

(B)

Figure 8. High-performance liquid chromatography (HPLC) chromatographs of the (A) standard and

(B) water fraction of garlic extract. SAC: S-allylcysteine.

\section{Discussion}

Asthma is marked by high concentrations of Th2 cytokines and increased immunoglobulin IgE and IgG1 [23,24]. A Der p-induced animal model is considered a suitable platform for studying allergic asthma because it shares many symptoms with human asthma [25]. This model is characterized by a thickening of the bronchial wall, airway mucosal edema, excessive mucus secretion, and increased inflammatory cell infiltration into the lung [26]. By using mice with Der p-induced allergic asthma, we executed the current study to evaluate the effects exerted by different fractions of garlic extracts. In our previous study, garlic extracts inhibited Der p-induced asthmatic airway inflammation through regulation of IgE and IgG1a levels and restoring the balance of Th1 and Th2 cytokines [21]. In the current study, we evaluated the effects and the mechanisms exerted by different fraction extracts of garlic using Der p-induced allergic asthma in mice.

Our results reveal that the WA fraction significantly reduced the observed serum levels of IgE and IgG1, inhibited the creation of chemokines, increased the levels of serum IgG2a, and balanced Th1 and Th2 cytokines in mice with Der p-induced allergic asthma. This is the first time that a WA fraction of garlic extract has been shown to grant protection against allergic asthma engendered by Der $p$ in a murine model. The primary virulence factor of asthma is the airway, and it is related to an imbalance of Th1 and Th2 cell hormones alongside increases in various immune cells and inflammatory mediators [27].

The extent of inflammatory cell infiltration in the lung affects asthma severity. Accumulation of eosinophils and lymphocytes around perivascular and per bronchial spaces causes bronchial epithelial hyperplasia and goblet cell modification in the bronchus, in addition to causing macrophage aggregation in the terminal bronchioles and alveolar spaces [28]. In the present study, Der p-induced asthmatic mice exhibited an elevation in the total cell count in the BALF. Histopathological analysis of their lung tissue revealed an increase in inflammatory cell infiltration in the lungs. However, treatment with the WA effectively inhibited the total cells, reduced inflammatory cells, and decreased inflammatory cell infiltration. Together, these findings point toward treatment with the WA having an anti-inflammatory effect on Der p-induced allergic asthma.

The primary role of chemokines is the migration of chemotactic cells, which migrate to the source of the chemokines according to the signal given by increased chemokine concentration [29]. Some chemokines control immune cell chemotaxis. Through releasing cytokines, $\mathrm{T}$ lymphocytes execute an integral function in immune and inflammatory response regulation processes [30]. In respiratory diseases, the literature confirms imbalance and dysfunction of Th1 and Th2 cells in the subpopulation 
of helper T lymphocytes as a key mechanism leading to allergic asthma [31]. Respiratory tract inflammation in asthma can be caused by Th2 cytokines [32,33]. In the immune system, Th2 cytokines, namely IL-5, -13 , and -4 , regulate the creation of IgE [34]. IL-13, -4 , and -5 are expressed abnormally in the allergic asthma mouse model [8]. In the present study, Th2 as well as Th1 cytokines were examined in mouse BALF. The results reveal the Der p-induced mouse Th2 cytokines IL-13, -4 , and -5 to be significantly increased and IFN- $\gamma$ and IL-12 (both constituting Th1 cytokines) to be significantly reduced. The WA fraction of garlic extract was noted to decrease the IL-13, -4 , and -5 levels but to further increase IFN- $\gamma$ levels. These findings are consistent with those from cell number analysis conducted on mouse BALF and with those from pathology analysis of mouse lung tissue. Overall, these results indicate that a WA of garlic lessens airway inflammation by regulating the Th1 and Th2 cytokine balance (i.e., Th2 cytokines are reduced and Th1 cytokines are increased).

The serum levels of Der p-specific immunoglobulins IgE and IgG1a were significantly reduced after treatment with the WA fraction. Previous studies have found that IL-13 and -4 stimulate B cells to synthesize IgE, a process associated with mast cell degranulation by cross-linking with IgE receptors $[30,31]$. Transcription factor NF- $\mathrm{KB}$ activation is affiliated with the Th2 cytokine creation as well as airway inflammation during allergic reactions [35]. Conversely, NF- $\mathrm{kB}$ signaling pathway inhibition was found to reduce Th2 cytokine creation and airway inflammation in asthmatic mice [36]. In this study, Der p-specific IgE inhibition engendered by WA fraction treatment might have inhibited the phosphorylation of NF- $\mathrm{KB}$ and mediated IL-13 and IL-4 switching to IgE.

NF- $\mathrm{KB}$ is a downstream component of the IL-6/PI3K/Akt pathway and is activated by phosphorylation of IKK by the PI3K/Akt pathway, resulting in IKB degradation. Thus, the Il-6/PI3K/Akt/ NF- $\mathrm{KB}$ pathway causes enhanced inflammatory expression in Der $\mathrm{p}$-induced allergic asthma. This study indicated that the PI3K/Akt/NF- $\mathrm{KB}$ pathway is an effective target for the WA fraction against inflammation response induced by Der p in A549 cells. The WA fraction expressed anti-inflammatory activity by inhibiting the IL-6/PI3K/Akt/NF-KB pathway.

Allergic asthma is a chronic respiratory disease. Reactive oxygen species (ROS) in the environment can cause oxidative damage to cells, and it is very likely to participate in the process of dust mites promoting sensitization. During the inflammation of the lungs, the imbalance of oxidants and antioxidants in the body is an important factor in causing cell damage. ROS is involved in maintaining the "redox homeostasis" of cells to protect cells from oxidative stress. However, ROS is produced in excess, the most common cause of which is the promotion of inflammatory cytokines such as NF- $\mathrm{kB}$. Oxidative stress is a harmful process that can cause damage to the airways and lungs. A previous study demonstrated that garlic essential oil and three of the individual compounds (diallyl trisulfide, ajoene, and allicin) inhibited spontaneous ROS production by neutrophils [37]. Moreover, PI3K plays an important role in the regulation of ROS production by human neutrophils. In this study, we demonstrated that WA fraction expressed anti-inflammatory activity by inhibiting the IL-6/PI3K/Akt/NF- $\kappa B$ pathway. Also, the pathological changes of airway were reversed after treating with WA fraction. Thus, the inhibition of ROS production may be one of the possible mechanisms in this work.

Mechanisms of allergic inflammation can contribute to the development of atherosclerosis and the pathogenesis of its clinical manifestations. Also, allergy-related cells such as basophils and mast cells may play a role in the regulation of lipid metabolism. Furthermore, it had been reported that allergic asthma and serum total IgE are associated with formation of arterial thrombosis [38]. In this study, we demonstrated that WA fraction will lower the IgE expression. Thus, the WA fraction of garlic extract may have potential in decreasing the allergy-related cardiovascular problems.

Recently, studies have indicated that obesity may have an effect on the induction of asthma as underlying the enhancement of asthma-associated inflammation due to increased (unbalanced) production of proinflammatory mediators in overgrown, inflamed, and dysregulated fat tissue [39]. In this study, we reported that WA fraction of garlic extract is effective on the restoration of Th1/Th2-related cytokine expression. Thus, we proposed that WA fraction of garlic extract may have positive effects on the treatment of obesity-induced allergic asthma. 
The results of this study reveal that the WA fraction expressed the greatest anti-inflammatory effect in mice with Der p-induced allergic asthma. These findings are of some interest and indicate that the water-soluble compounds of garlic are likely to contain major active components. A previous study indicated that sulfide-derived compounds play major roles in the pharmacological activities of garlic [40]. SAC is an important hydrophilic component of garlic, and it was observed in the HPLC profile in this study. Previous research has found that SAC has anti-inflammatory activity [41]. It is therefore worth investigating further whether SAC or other water-soluble components of garlic act against Der p-engendered allergic asthma.

\section{Materials and Methods}

\subsection{Chemicals and Drugs}

Dichloromethane, ethylacetate, n-butanol, and n-hexane were purchased from Sigma-Aldrich (Sigma-Aldrich Co., St. Louis, MO, USA). Akt, p-Akt, IL-6, NF-kB, p-NF-kB and PI3-K antibodies were purchased from Abcam, Cambridge, USA. Ikk antibody was purchased from Cell Signaling Technology Danvers, USA. $1 \mathrm{~g}$ of Der $\mathrm{p}$ (Thermo Fisher Scientific, Waltham, MA, USA) was extracted using diethyl ether and then the filtrate was lyophilised to obtain Der $\mathrm{p}$ ) extract. The extract was dissolved in sterile saline, filtered through a $0.22 \mu \mathrm{m}$ filter, and stored at $-80{ }^{\circ} \mathrm{C}$ before use.

\subsection{Preparation of Extracts}

Garlic was collected in Taichung City, Taiwan. The peeled and non-chopped garlic (10 kg) was weighed and extracted using various polar solvents. First, the garlic was extracted using n-hexane (20L) a minimum of three times. Filtrates were subsequently collected and concentrated to obtain HE. The residues were then extracted in sequence with dichloromethane, ethyl acetate, n-butanol, and water as in the aforementioned steps, resulting in five fractional extracts of garlic: $\mathrm{HE}(21.7 \mathrm{~g}, 0.22 \%)$, DI $(25.7 \mathrm{~g}, 0.26 \%)$, EA $(18.1 \mathrm{~g}, 0.18 \%), \mathrm{BU}(191.0 \mathrm{~g}, 1.91 \%)$, and WA $(514.0 \mathrm{~g}, 5.14 \%)$, as seen in Figure 9.

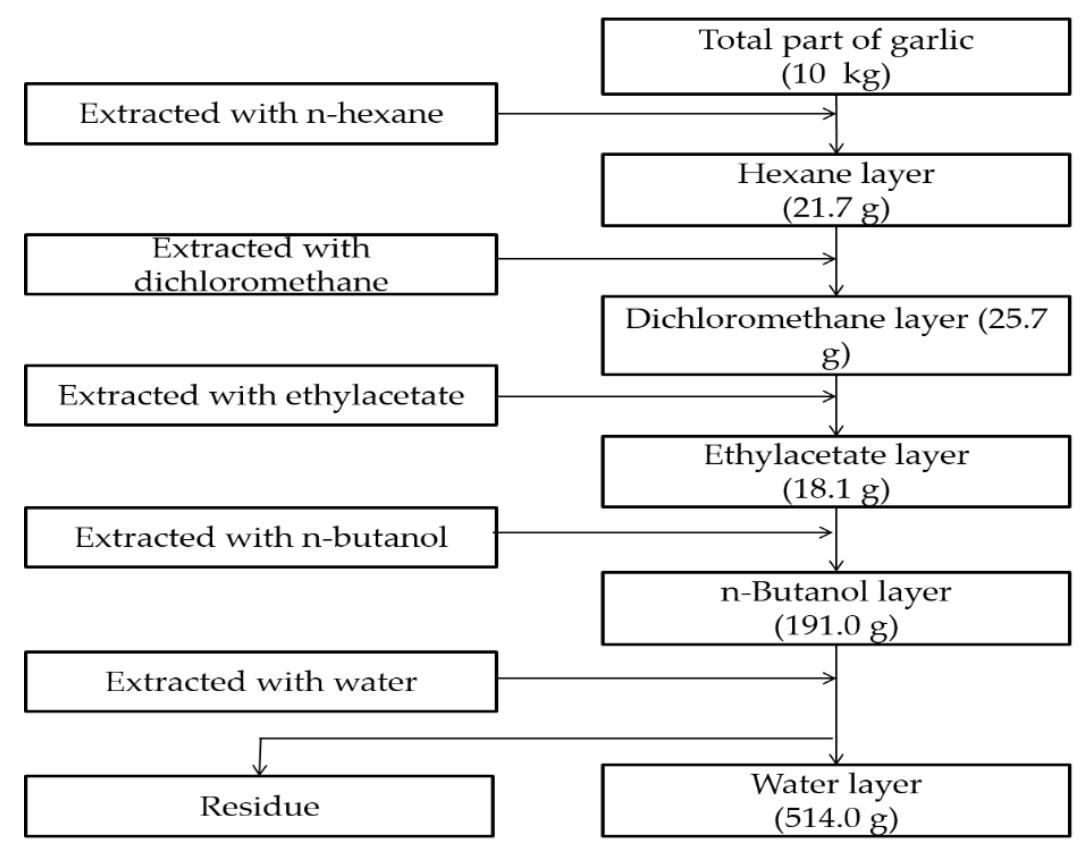

Figure 9. Fraction extraction procedure. The garlic was extracted using n-hexane, followed by dichloromethane, ethylacetate, n-butanol, and water. 


\subsection{Experimental Animals}

Male BALB/c mice that were determined to be aged six to eight weeks were procured from BioLASCO Taiwan (Taipei, Taiwan) and housed and cared for according to the recommendations set forth by the NIH Guide for the Care and Use of Laboratory Animals. The entirety of the animals were raised in a specific-pathogen-free lab involving a fixed temperature, namely $22 \pm 1{ }^{\circ} \mathrm{C}$, and relative humidity, namely $55 \% \pm 5 \%$, in addition to a 12 -h light-dark cycle. In addition, water and regulation laboratory chow were available to the acquired animals ad libitum. The Institutional Animal Care and Use Committee of Da-Yeh University (Permit Number: 105024, 26 October 2016) ratified the procedures of the executed experiment.

\subsection{Establishing an Allergic Asthma Model}

Through random division, the animals were placed into seven groups $(n=10)$. Group 1 (control) and Group 2 (Der p) were orally given $0.9 \%$ saline water. Groups $3-7$ were orally administered with $80 \mathrm{mg} / \mathrm{kg}$ of one of the extracts (HE, DI, EA, BU, and WA, respectively). The doses were chosen according to previous studies [21,42]. The investigator was blinded to the treatment groups.

As shown in Figure 10, on days 1 and 7, Groups 2-7 were subcutaneously injected with emulsion $(50 \mu \mathrm{L})$ containing Der p (50 $\mu \mathrm{g})$ in incomplete Freund's adjuvant (Difco, Detroit, MI, USA); the injections were delivered at the base of their tails; on these days, the acquired animals in Group 1 were injected with $50 \mu \mathrm{L}$ of saline. On day 14 , a shot of tiletamine/zolazepam (Zoletil ${ }^{\circledR} 50$, Virbac Corporation, Carros, France), given intraperitoneally at $20 \mathrm{mg} / \mathrm{kg}$ body weight, was administered to anesthetize the mice. With the exception of Group 1, the acquired mice were subjected to treatment using an intratracheal instillation of $50 \mu \mathrm{L}$ of Der $\mathrm{p}(1.0 \mathrm{mg} / \mathrm{mL})$, followed by maintaining them upright for a period of $1 \mathrm{~min}$ until the restoration of normal breathing [43]. After $72 \mathrm{~h}$ since the last Der $\mathrm{p}$ challenge, mice were sacrificed. Lung and trachea tissues were removed for histological analysis. Serum and BALF were collected for analysis.

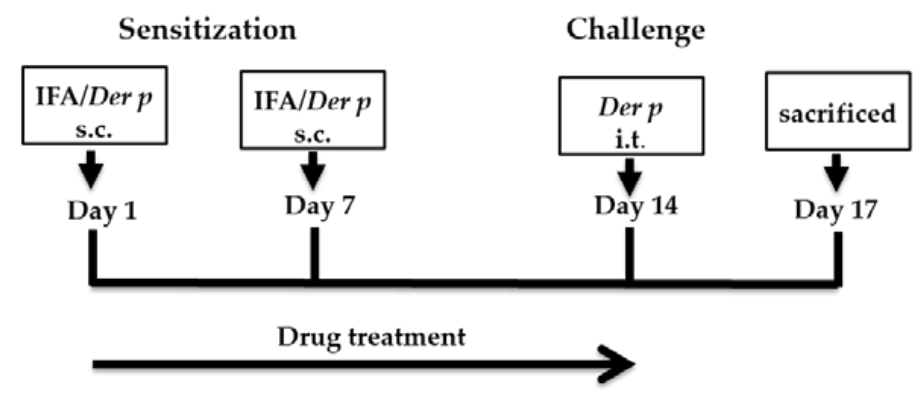

Figure 10. Experimental protocol of allergic sensitization and challenge.

\subsection{Preparing BALF and Counting Inflammatory Cells}

In the executed study, total cells and BALF were collected according to He et al. [44]. Briefly, after $72 \mathrm{~h}$ since the last Der $\mathrm{p}$ induction, the mice were euthanized under anesthesia. Subsequently, the lungs were lavaged using a syringe containing $1 \mathrm{~mL}$ of ice sterile saline solution. This process was repeated three times, and then the lavage fluid was collected. The collected lavage fluid was subjected to a 10-min centrifugation process executed at $4{ }^{\circ} \mathrm{C}$ and $1200 \mathrm{rpm}$, followed by gathering and keeping the supernatant at $-80^{\circ} \mathrm{C}$. PBS constituted the medium for resuspending each tube's cell pellet; a hemocytometer was used to measure the total cell count.

\subsection{Histological Lung Assessment}

Each lung was placed in an embedding cassette after being fixed in $10 \%$ neutral formalin. The lung tissue was first dehydrated, and, after standing overnight, the abovementioned tissue was inserted into paraffin and chopped into approximately $4-5-\mu \mathrm{m}$ sections by using a microtome. The experiment 
was performed after the paraffin was dried and fixed. After the execution of staining performed by employing hematoxylin and eosin (H\&E), the specific conditions and histopathological changes of each group of lung cells were examined under a light microscope, during which the degree of injury was compared and photographed. The severity of lesions in the lungs was graded according to the methods described by Shackelford et al. [22]. The degree of lesions was graded from one to five depending on severity: $1=$ minimal $(<1 \%) ; 2$ : slight $(1-25 \%) ; 3=$ moderate $(26-50 \%) ; 4=$ moderately severe $(51-75 \%)$; $5=$ severe/high (76-100\%). Mean histopathological scores were calculated by dividing the sum of the score per grade of affected mice by the total number of examined mice.

\subsection{Measurement of Type 1 Thelper (Th1) and Th2 Cytokine Concentrations in BALF}

Following previous studies [45,46], IFN- $\gamma$ and IL-12, $-13,-4$, and -5 levels in the lavage fluids of the lungs from the control, Der $\mathrm{p}$, and garlic extract-fed mice ventilated ex vivo with either the protective or the injurious strategy were determined in the laboratory by using mice-specific ELISA kits (BioSource, Camarillo, CA, USA). For subsequent analyses, a Bio-Plex assay was executed to determine the IFN- $\gamma$ and IL-12, $-13,-4$, and -5 levels, which were then read on a Luminex-100 system (Luminex Co., Austin, TX, USA). The analysis of the results was executed via Bio-Plex Manager software (Bio-Rad Laboratories, Hercules, CA, USA).

\subsection{Der p-Specific Serum IgE/IgG1/IgG2a Concentrations}

In this study, serum IgE/IgG1/IgG2a concentrations were quantified via appropriate ELISA kits per instructions provided by the relevant manufacturer (Promega, Madison, WI, USA).

\subsection{Measurement of Pro-Inflammatory Cytokine Concentrations in Lung Tissues}

In this study, the inflammatory cytokine IL-1 $\beta$ (ab100704) / IL-6 (ab100712) / TNF- $\alpha$ (ab100785) concentrations were quantified by appropriate ELISA Kits according to the instructions provided by the relevant manufacturer (Abcam, Cambridge, UK).

\subsection{Cell Culture}

A549 cells were purchased from the Culture Collection and Research Center of the Food Industry Institute (Hsin-Chiu City, Taiwan). The cells were cultured in F-12K medium containing $10 \%$ fetal bovine serum (FBS) and $1 \%$ Penicillin-streptomycin-amphotercin solution (PSA), and placed in a $37^{\circ} \mathrm{C}$, $5 \% \mathrm{CO}_{2}$ incubator for growth. When the cells reached approximately $80 \%$ confluence, subculture was carried out; the cells were suspended in a liquid by adding $0.05 \%$ Trypsin-EDTA and cultured in a plate at a number of $1 \times 10^{6}$ cells. After 24 hours of plating, Der p $(5 \mu \mathrm{g} / \mathrm{mL})$ and WA extract $(100,200$, 500 , or $1000 \mu \mathrm{g} / \mathrm{mL}$ ) was added and reacted for $24 \mathrm{~h}$ The cells were harvested via treatment with cell lysis buffer for further studies.

\subsection{Western Blotting Analysis}

Total protein lysate from the cells was extracted in lysis buffer containing a mixture of protease and phosphatase inhibitors (Sigma-Aldrich). Protein concentration was determined using a BCA protein assay kit (Pierce Biotechnology, Rockford, IL, USA). Protein lysate $(50 \mu \mathrm{g})$ was separated by $10 \%$ SDS-PAGE and transferred to a polyvinylidene fluoride membrane (Millipore, Billerica, MA, USA). The membrane was blocked in Tris buffered saline containing 3\% bovine serum albumin in Tween at $25{ }^{\circ} \mathrm{C}$ for 1 hour. After washing, the membrane was incubated overnight at $4{ }^{\circ} \mathrm{C}$ in the following primary anti-IL-6 (1:1000), PI3-K (1:1000), I $\kappa$ kinase (Ikk) (1:500), p-Akt (1:500), Akt (1:500), p-NF-kB (1:500), NF- $\mathrm{B}$ (1:1000) antibodies. After washing the membrane with TBS-T, the blot was incubated in a 1/5000 dilution of horseradish peroxidase-conjugated secondary antibody at $25^{\circ} \mathrm{C}$ for 1 hour. Protein bands were visualized using an enhanced chemiluminescence kit (PerkinElmer, Boston, MA, USA). Actin (Millipore) was used as an internal control. The optical density of the bands were determined by software. 


\subsection{HPLC Analysis of the WA}

For the WA and standard (S-allylcysteine, SAC), a high-performance liquid chromatography (HPLC) profile was established. The instruments comprised a Shimadzu LC-10Avp HPLC system and SPD-M10A Diode array detector. Analyses were executed in the experiment by employing a COSMOSIL 5C18-AR II column $\left(4.6 \times 250 \mathrm{~mm}^{2}, 5 \mu \mathrm{m}\right)$, with the mobile phase being observed to contain acetonitrile and $10 \mathrm{mM} \mathrm{KH}_{2} \mathrm{PO}_{4}$ with an isocratic elution (2:98). All standards and samples in the experiment were passed through a $0.45-\mu \mathrm{m}$ Minipore filter prior to injection $(10 \mu \mathrm{L})$ into the column. A 220-nm detection wavelength was employed, and the determined flow rate was $1.0 \mathrm{~mL} / \mathrm{min}$. Each analysis required $20 \mathrm{~min}$.

\subsection{Statistical Analysis}

Herein, the derived results are presented as the mean \pm SEM according to each group's sample number (n). With regard to the differences among multiple groups, the corresponding significance was evaluated using analysis of variance (ANOVA). On establishing significance between groups, Duncan's multiple range test was employed to compare two specific groups' mean values via SPSS for Windows, version 17 (IBM, Chicago, IL, USA). In addition, statistical significance was set in this study to be $p<0.05$.

\section{Conclusions}

Using a Der p-engendered allergic asthma model in mice, we estimated the anti-inflammatory effects of different fractions of garlic extracts (HE, DI, EA, BU, and WA). The WA fraction had a clear protective effect against allergic asthma. Specifically, treatment with the WA fraction significantly decreased airway inflammation and reduced expression of IL-13, -4 , and -5 in BALF as well as serum IgE and IgG1. Therefore, the WA fraction could regulate the imbalance between Th1 and Th2 by inhibiting Th2 cytokines and inflammatory protein. Histological results reveal that the WA fraction attenuated Der p-induced inflammatory cell infiltration in lung tissue and cell infiltration within the submucosal layer of the trachea. The WA fraction also expressed anti-inflammatory activity by inhibiting IL-6/PI3K/Akt/NF- $\mathrm{kB}$ signal pathways. In conclusion, the WA fraction was effective in treating Th2-type allergic responses in asthma engendered by Der $p$ in a murine model, indicating that it might be a protective agent for use in patients with allergic asthma.

Author Contributions: C.-C.H., K.-F.L. and P.-C.L. performed the experiments and analyzed the data; Y.-T.H. and W.-S.L. prepared figures and interpreted the data; C.-C.H. and K.-F.L. wrote the main manuscript text; W.-H.P. and J.-C.T. designed the research and revised the manuscript and discussed data. All authors participated in the preparation of the manuscript and approved the final manuscript.

Funding: This research was funded by Ministry of Science and Technology (grant number 106-2320-B-212-001-MY2) and Cheng Ching Hospital (grant number CCGH-DYU-106-004).

Acknowledgments: We thank Jiunn-Wang Liao for their assistance in our experiments. We also thank Wallace Academic for their editing services.

Conflicts of Interest: The authors declare no conflict of interest.

\section{Abbreviations}

$\begin{array}{ll}\text { Der p } & \text { Dermatophagoides pteronyssinus } \\ \text { BALF } & \text { bronchoalveolar lavage fluid } \\ \text { Th1 } & \text { Type 1 T helper } \\ \text { Th2 } & \text { Type 2 T helper } \\ \text { IgE } & \text { Immunoglobulin E } \\ \text { IgG1 } & \text { Immunoglobulin G1 } \\ \text { IgG2a } & \text { Immunoglobulin G2a } \\ \text { IL-12 } & \text { Interleukin-12 } \\ \text { IL-13 } & \text { Interleukin-13 }\end{array}$




$\begin{array}{ll}\text { IL-4 } & \text { Interleukin-4 } \\ \text { IL-5 } & \text { Interleukin-5 } \\ \text { IL-6 } & \text { Interleukin-6 } \\ \text { IL-1 } \beta & \text { Interleukin-1 } \beta \\ \text { IFA } & \text { Incomplete Freund's adjuvant } \\ \text { TNF- } \alpha & \text { Tumor necrosis factor- } \alpha \\ \text { PI3K } & \text { Phosphoinositide 3-kinases } \\ \text { NF-kB } & \text { Nuclear factor- } \kappa \text { B } \\ \text { IKK } & \text { IkB kinase } \\ \text { HE } & \text { n-Hexane extracts } \\ \text { DI } & \text { Dichloromethane extracts } \\ \text { EA } & \text { Ethyl acetate extracts } \\ \text { BU } & \text { n-Butanol extracts } \\ \text { WA } & \text { Water extracts } \\ \text { SAC } & \text { S-allyl cysteine sulfoxide }\end{array}$

\section{References}

1. Zhang, G.; Wang, P.; Yang, G.; Cao, Q.; Wang, R. The inhibitory role of hydrogen sulfide in airway hyperresponsiveness and inflammation in a mouse model of asthma. Am. J. Pathol. 2013, 182, 1188-1195. [CrossRef] [PubMed]

2. Gohy, S.T.; Hupin, C.; Pilette, C.; Ladjemi, M.Z. Chronic inflammatory airway diseases: The central role of the epithelium revisited. Clin. Exp. Allergy 2016, 46, 529-542. [CrossRef] [PubMed]

3. Holgate, S.T. The airway epithelium is central to the pathogenesis of asthma. Allergol. Int. 2008, 57, 1-10. [CrossRef] [PubMed]

4. Guilbert, T.W.; Bacharier, L.B.; Fitzpatrick, A.M. Severe asthma in children. J. Allergy Clin. Immunol. Pract. 2014, 2, 489-500. [CrossRef] [PubMed]

5. Potaczek, D.P.; Harb, H.; Michel, S.; Alhamwe, B.A.; Renz, H.; Tost, J. Epigenetics and allergy: From basic mechanisms to clinical applications. Epigenomics. 2017, 9, 539-571. [CrossRef]

6. Alaskhar Alhamwe, B.; Khalaila, R.; Wolf, J.; von Bulow, V.; Harb, H.; Alhamdan, F.; Hii, C.S.; Prescott, S.L.; Ferrante, A.; Renz, H.; et al. Histone modifications and their role in epigenetics of atopy and allergic diseases. Allergy. Asthma. Clin. Immunol. 2018, 14,39. [CrossRef] [PubMed]

7. Wang, J.; Jin, R.G.; Xiao, L.; Wang, Q.J.; Yan, T.H. Anti-asthma effects of synthetic salidroside through regulation of Th1/Th2 balance. Chin. J. Nat. Med. 2014, 12, 500-504. [CrossRef]

8. Ashraf, M.I.; Shahzad, M.; Shabbir, A. Oxyresveratrol ameliorates allergic airway inflammation via attenuation of IL-4, IL-5, and IL-13 expression levels. Cytokine 2015, 76, 375-381. [CrossRef]

9. Maezawa, Y.; Nakajima, H.; Kumano, K.; Kubo, S.; Karasuyama, H.; Iwamoto, I. Role of IgE in Th2 cell-mediated allergic airway inflammation. Int. Arch. Allergy Immunol. 2003, 131 (Suppl. 1), 2-6. [CrossRef]

10. Thomson, N.C.; Spears, M. Inhaled corticosteroids for asthma: On-demand or continuous use. Expert. Rev. Respir. Med. 2013, 7, 687-699. [CrossRef]

11. Mazzon, E.; Cuzzocrea, S. Role of TNF-alpha in lung tight junction alteration in mouse model of acute lung inflammation. Respir. Res. 2007, 8, 75. [CrossRef] [PubMed]

12. Guimaraes, P.M.; Scavuzzi, B.M.; Stadtlober, N.P.; Franchi Santos, L.; Lozovoy, M.A.B.; Iriyoda, T.M.V.; Costa, N.T.; Reiche, E.M.V.; Maes, M.; Dichi, I.; et al. Cytokines in systemic lupus erythematosus: Far beyond Th1/Th2 dualism lupus: Cytokine profiles. Immunol. Cell Biol. 2017, 95, 824-831. [CrossRef] [PubMed]

13. Hunter, C.A.; Jones, S.A. IL-6 as a keystone cytokine in health and disease. Nat. Immunol. 2015, 16, 448-457. [CrossRef] [PubMed]

14. Jo, H.A.; Kim, J.Y.; Yang, S.H.; Han, S.S.; Joo, K.W.; Kim, Y.S.; Kim, D.K. The role of local IL6/JAK2/STAT3 signaling in high glucose-induced podocyte hypertrophy. Kidney Res. Clin. Pract. 2016, 35, 212-218. [CrossRef] [PubMed]

15. Gagliardo, R.; Chanez, P.; Profita, M.; Bonanno, A.; Albano, G.D.; Montalbano, A.M.; Pompeo, F.; Gagliardo, C.; Merendino, A.M.; Gjomarkaj, M. IkappaB kinase-driven nuclear factor-kappaB activation in patients with asthma and chronic obstructive pulmonary disease. J. Allergy Clin. Immunol. 2011, 128, 635-45.e1-2. [CrossRef] [PubMed] 
16. Gu, X.; Zhang, Q.; Du, Q.; Shen, H.; Zhu, Z. Pinocembrin attenuates allergic airway inflammation via inhibition of NF-kappaB pathway in mice. Int. Immunopharmacol. 2017, 53, 90-95. [CrossRef] [PubMed]

17. Alali, F.Q.; El-Elimat, T.; Khalid, L.; Hudaib, R.; Al-Shehabi, T.S.; Eid, A.H. Garlic for Cardiovascular Disease: Prevention or Treatment? Curr. Pharm. Des. 2017, 23, 1028-1041. [CrossRef] [PubMed]

18. Sun, Y.E.; Wang, W.; Qin, J. Anti-hyperlipidemia of garlic by reducing the level of total cholesterol and low-density lipoprotein: A meta-analysis. Medicine (Baltimore) 2018, 97, e0255. [CrossRef]

19. Padiya, R.; Banerjee, S.K. Garlic as an anti-diabetic agent: Recent progress and patent reviews. Recent Pat. Food Nutr. Agric. 2013, 5, 105-127. [CrossRef]

20. Zamani, A.; Vahidinia, A.; Ghannad, M.S. The effect of garlic consumption on Th1/Th2 cytokines in phytohemagglutinin (PHA) activated rat spleen lymphocytes. Phytother. Res. 2009, 23, 579-581. [CrossRef]

21. Hsieh, C.C.; Peng, W.H.; Tseng, H.H.; Liang, S.Y.; Chen, L.J.; Tsai, J.C. The Protective Role of Garlic on Allergen-Induced Airway Inflammation in Mice. Am. J. Chin. Med. 2019, 47, 1099-1112. [CrossRef] [PubMed]

22. Shackelford, C.; Long, G.; Wolf, J.; Okerberg, C.; Herbert, R. Qualitative and quantitative analysis of nonneoplastic lesions in toxicology studies. Toxicol. Pathol. 2002, 30, 93-96. [CrossRef] [PubMed]

23. van Halteren, A.G.; van der Cammen, M.J.; Cooper, D.; Savelkoul, H.F.; Kraal, G.; Holt, P.G. Regulation of antigen-specific IgE, IgG1, and mast cell responses to ingested allergen by mucosal tolerance induction. J. Immunol. 1997, 159, 3009-3015. [PubMed]

24. Yano, S.; Umeda, D.; Yamashita, T.; Ninomiya, Y.; Sumida, M.; Fujimura, Y.; Yamada, K.; Tachibana, H. Dietary flavones suppresses IgE and Th2 cytokines in OVA-immunized BALB/c mice. Eur. J. Nutr. 2007, 46, 257-263. [CrossRef] [PubMed]

25. HuangFu, T.; Lim, L.H.; Chua, K.Y. Efficacy evaluation of Der $p 1$ DNA vaccine for allergic asthma in an experimental mouse model. Vaccine 2006, 24, 4576-4581. [CrossRef] [PubMed]

26. Roche, N.; Chinet, T.C.; Huchon, G.J. Allergic and nonallergic interactions between house dust mite allergens and airway mucosa. Eur. Respir. J. 1997, 10, 719-726. [PubMed]

27. Shin, I.S.; Park, J.W.; Shin, N.R.; Jeon, C.M.; Kwon, O.K.; Kim, J.S.; Kim, J.C.; Oh, S.R.; Ahn, K.S. Melatonin reduces airway inflammation in ovalbumin-induced asthma. Immunobiology 2014, 219, 901-908. [CrossRef]

28. Halwani, R.; Vazquez-Tello, A.; Sumi, Y.; Pureza, M.A.; Bahammam, A.; Al-Jahdali, H.; Soussi-Gounni, A.; Mahboub, B.; Al-Muhsen, S.; Hamid, Q. Eosinophils induce airway smooth muscle cell proliferation. J. Clin. Immunol. 2013, 33, 595-604. [CrossRef]

29. Debes, G.F.; Dahl, M.E.; Mahiny, A.J.; Bonhagen, K.; Campbell, D.J.; Siegmund, K.; Erb, K.J.; Lewis, D.B.; Kamradt, T.; Hamann, A. Chemotactic responses of IL-4-, IL-10-, and IFN-gamma-producing CD4 ${ }^{+}$T cells depend on tissue origin and microbial stimulus. J. Immunol. 2006, 176, 557-566. [CrossRef]

30. Profumo, E.; Buttari, B.; Saso, L.; Capoano, R.; Salvati, B.; Rigano, R. T lymphocyte autoreactivity in inflammatory mechanisms regulating atherosclerosis. Sci. World J. 2012, 2012, 157534. [CrossRef]

31. Leiria, L.O.; Martins, M.A.; Saad, M.J. Obesity and asthma: Beyond T(H)2 inflammation. Metabolism 2015, 64, 172-181. [CrossRef] [PubMed]

32. Kim, Y.; Lee, S.; Kim, Y.S.; Lawler, S.; Gho, Y.S.; Kim, Y.K.; Hwang, H.J. Regulation of Th1/Th2 cells in asthma development: A mathematical model. Math. Biosci. Eng. 2013, 10, 1095-1133. [PubMed]

33. Yun, X.; Shang, Y.; Li, M. Effect of Lactobacillus salivarius on Th1/Th2 cytokines and the number of spleen $\mathrm{CD}^{+} \mathrm{CD}^{+} 5^{+}$Foxp3 $^{+}$Treg in asthma Balb/c mouse. Int. J. Clin. Exp. Pathol. 2015, 8, 7661-7674. [PubMed]

34. Maeda, S.; Yanagihara, Y. [Inflammatory cytokines (IL-4, IL-5 and IL-13)]. Nihon Rinsho. 2001, 59, 1894-1899. [PubMed]

35. Wang, J. Casticin alleviates lipopolysaccharide-induced inflammatory responses and expression of mucus and extracellular matrix in human airway epithelial cells through Nrf2/Keap1 and NF-kappaB pathways. Phytother. Res. 2018, 32, 1346-1353. [CrossRef] [PubMed]

36. Schuliga, M. NF-kappaB Signaling in Chronic Inflammatory Airway Disease. Biomolecules 2015, 5, $1266-1283$. [CrossRef] [PubMed]

37. Schepetkin, I.A.; Kirpotina, L.N.; Khlebnikov, A.I.; Balasubramanian, N.; Quinn, M.T. Neutrophil Immunomodulatory Activity of Natural Organosulfur Compounds. Molecules 2019, 24, 1809. [CrossRef] [PubMed]

38. Potaczek, D.P. Links between allergy and cardiovascular or hemostatic system. Int. J. Cardiol. 2014, 170, 278-285. [CrossRef] 
39. Miethe, S.; Guarino, M.; Alhamdan, F.; Simon, H.U.; Renz, H.; Dufour, J.F.; Potaczek, D.P.; Garn, H. Effects of obesity on asthma: Immunometabolic links. Pol. Arch. Intern. Med. 2018, 128, 469-477. [CrossRef]

40. Arreola, R.; Quintero-Fabian, S.; Lopez-Roa, R.I.; Flores-Gutierrez, E.O.; Reyes-Grajeda, J.P.; Carrera-Quintanar, L.; Ortuno-Sahagun, D. Immunomodulation and anti-inflammatory effects of garlic compounds. J. Immunol. Res. 2015, 2015, 401630. [CrossRef]

41. Johnson, P.; Loganathan, C.; Iruthayaraj, A.; Poomani, K.; Thayumanavan, P. S-allyl cysteine as potent anti-gout drug: Insight into the xanthine oxidase inhibition and anti-inflammatory activity. Biochimie 2018, 154, 1-9. [CrossRef] [PubMed]

42. Gilhotra, N.; Dhingra, D. GABAergic and nitriergic influence in antianxiety-like Activity of Garlic in Mice. J. Appl. Pharm. Sci. 2016, 6, 77-85. [CrossRef]

43. Chen, C.L.; Wang, S.D.; Zeng, Z.Y.; Lin, K.J.; Kao, S.T.; Tani, T.; Yu, C.K.; Wang, J.Y. Serine protease inhibitors nafamostat mesilate and gabexate mesilate attenuate allergen-induced airway inflammation and eosinophilia in a murine model of asthma. J. Allergy Clin. Immunol. 2006, 118, 105-112. [CrossRef] [PubMed]

44. He, J.; Lv, L.; Wang, Z.; Huo, C.; Zheng, Z.; Yin, B.; Jiang, P.; Yang, Y.; Li, J.; Gao, Y.; et al. Pulvis Fellis Suis extract attenuates ovalbumin-induced airway inflammation in murine model of asthma. J. Ethnopharmacol. 2017, 207, 34-41. [CrossRef] [PubMed]

45. Woolard, M.D.; Hudig, D.; Tabor, L.; Ivey, J.A.; Simecka, J.W. NK cells in gamma-interferon-deficient mice suppress lung innate immunity against Mycoplasma spp. Infect. Immun. 2005, 73, 6742-6751. [CrossRef]

46. Sabo-Attwood, T.; Ramos-Nino, M.; Bond, J.; Butnor, K.J.; Heintz, N.; Gruber, A.D.; Steele, C.; Taatjes, D.J.; Vacek, P.; Mossman, B.T. Gene expression profiles reveal increased mClca3 (Gob5) expression and mucin production in a murine model of asbestos-induced fibrogenesis. Am. J. Pathol. 2005, 167, 1243-1256. [CrossRef]

(C) 2019 by the authors. Licensee MDPI, Basel, Switzerland. This article is an open access article distributed under the terms and conditions of the Creative Commons Attribution (CC BY) license (http://creativecommons.org/licenses/by/4.0/). 